\title{
No. 1832
}

\section{ARGENTINA, AUSTRALIA, BELGIUM, BOLIVIA, BRAZIL, etc.}

Treaty of Peace with Japan (with two declarations). Signed at San Francisco, on 8 September 1951

Official texts: English, French, Spanish and Japanese.

Registered by the United States of America on 21 August 1952.

\section{ARGENTINE, AUSTRALIE, BELGIQUE, BOLIVIE, BRÉSIL, etc.}

Traité de paix avec le Japon (avec deux déclarations). Signé à San-Francisco, le 8 septembre 1951

Textes officiels anglais, français, espagnol et japonais.

Enregistré par les Etats-Unis d'Amérique le 21 août 1952. 


\section{No. 1832. TREATY ${ }^{1}$ OF PEACE WITH JAPAN. SIGNED AT SAN FRANCISCO, ON 8 SEPTEMBER 1951}

Whereas the Allied Powers and Japan are resolved that henceforth their relations shall be those of nations which, as sovereign equals, cooperate in friendly association to promote their common welfare and to maintain international peace and security, and are therefore desirous of concluding a Treaty of Peace which will settle questions still outstanding as a result of the existence of a state of war between them;

1 In accordance with article $23(a)$ the Treaty came into force initially on 28 April 1952 with respect to the following States by virtue of the deposit by those States with the Government of the United States of America of their respective instruments of ratification on the dates indicated :

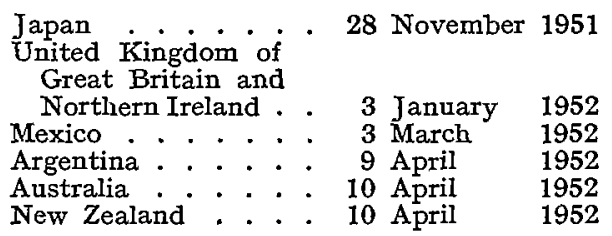

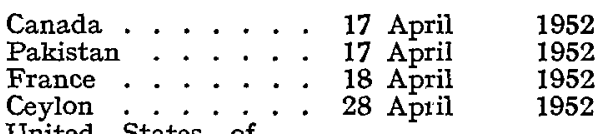

United States of

America 1952

(with a deciaration)*

It came into force subsequently on the dates indicated with respect to the following other States by deposit of the instrument of ratification with the Government of the United States of America :

El Salvador .... 6 May 1952 (with the following declarations)**

"I) El Salvador no acepta ni ratifica Ios compromisos que otros Estados puedan haber contraido con respecto a la transferencia o final disposición de los territorios enumerados en el artículo Segundo del Tratado de Paz con el Japón, en todos aquelios casos en que no se haya consultado y acatado la voluntad libremente expresada por las poblaciones afectadas. Esta reserva se aplica a la transferencia de las Islas Kuriles, de una parte de la Isla Sajaline (Sakhalin) y a cualquier otro caso análogo, incluyendo además todo compromiso sobre la Isla de Formosa ; y

“II) No podrá tener efecto alguno en E1Salvador debido a que son contrarias a su Constitución Política, las

\begin{tabular}{|c|c|c|c|c|c|c|c|}
\hline \multicolumn{8}{|c|}{$\begin{array}{l}\text { disposiciones del Artículo XIV del Tratado de Paz } \\
\text { con el Japón que autorizan la confiscación de bienes } \\
\text { de personas naturales o jurídicas japonesas." }\end{array}$} \\
\hline Brazil & & & & & 20 & May & 1952 \\
\hline Cambodia & & & & & 2 & June & 1952 \\
\hline Dominican & Rep & public & & & 6 & June & 1952 \\
\hline Ethiopia . & & & & - & 12 & June & 1952 \\
\hline Peru & . & . & - & . & 17 & June & 1952 \\
\hline Netherlands & ls. & - . & - & • & 17 & June & 1952 \\
\hline Viet-Nam . & . . & . . & - & • & 18 & June & 1952 \\
\hline Iway & & . . & . & & 19 & June & 1952 \\
\hline nezuela. & & . . & 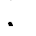 & & 20 & June & 1952 \\
\hline Laos. & • & . . & . & - & 20 & June & 1952 \\
\hline
\end{tabular}

disposiciones del Artículo XIV del Tratado de Paz con el Japón que autorizan la confiscación de bienes de personas naturales o juridicas japonesas."

- "As part of such advice and consent the Senate states that nothing the treaty contains is deemed to diminish or prejudice, in favor of the Soviet Union, the right, title, and interest of Japan, or the Allied Powers as defined is said treaty, in and to South Sakhalin and its adjacent islands, the Kurile Islands, the Habomai Islands, the Island of Shikotan, or any other territory, rights, or interests possessed by Japan on December 7,1941 , or to confer any right, title, or benefit therein or thereto on the Soviet Union; and also that nothing in the said treaty, or the advice and consent of the Senate to the ratification thereof, implies recognition on the part of the United States of the provisions in favor of the Soviet Uni nocontained in the so-called 'Yaita agreement' regarding Japan of February 11, 1945."

\section{[Translatron - Traduction]}

** "EI Salvador does not accept nor ratify the commitments which the other nations may have contracted with respect to the transference or final disposition of those territories enumerated in article 2 of the Treaty of Peace with Japan, in all those cases in which the freely expressed will of the affected populations was not consulted and respected. This reservation applies to the transference of the Kurile Islands, a part of the Island of Sakhalin, and any otherisimilar case, including, furthermore, any commitment concerring the Island of Formosa.

"The provisions of article 14 of the Treaty of Peace with Japan which authorizes the confiscation of the property of Japanese natural and juridical persons can bave no effect in El Salvador, in view of the fact that they are contrary to its Political Constitution." 
Whereas Japan for its part declares its intention to apply for membership in the United Nations and in all circumstances to conform to the principles of the Charter of the United Nations; to strive to realize the objectives of the Universal Declaration of Human Rights; to seek to create within Japan conditions of stability and well-being as defined in Articles 55 and 56 of the Charter of the United Nations and already initiated by post-surrender Japanese legislation; and in public and private trade and commerce to conform to internationally accepted fair practices;

Whereas the Allied Powers welcome the intentions of Japan set out in the foregoing paragraph ;

The Allied Powers and Japan have therefore determined to conclude the present Treaty of Peace, and have accordingly appointed the undersigned Plenipotentiaries, who, after presentation of their full powers, found in good and due form, have agreed on the following provisions :

\section{CHAPTER I}

\section{PEACE}

\section{Article 1}

(a) The state of war between Japan and each of the Allied Powers is terminated as from the date on which the present Treaty comes into force between Japan and the Allied Power concerned as provided for in Article 23.

(b) The Allied Powers recognize the full sovereignty of the Japanese people over Japan and its territorial waters.

\section{CHAPTER II}

\section{TERRITORY}

\section{Article 2}

(a) Japan, recognizing the independence of Korea, renounces all right, title and claim to Korea, including the islands of Quelpart, Port Hamilton and Dagelet.

(b) Japan renounces all right, title and claim to Formosa and the Pescadores.

(c) Japan renounces all right, title and claim to the Kurile Islands, and to that portion of Sakhalin and the islands adjacent to it over which Japan acquired sovereignty as a consequence of the Treaty of Portsmouth of September 5, 1905.1

(d) Japan renounces all right, title and claim in connection with the League of Nations Mandate System, and accepts the action of the United Nations Security

${ }^{1}$ De Martens: Nouveau Recueil général de Traités, deuxième série, tome XXXIIT, p. 3. No. 1832 
Council of April 2, 1947, extending the trusteeship system to the Pacific Islands formerly under mandate to Japan. ${ }^{1}$

(e) Japan renounces all claim to any right or title to or interest in connection with any part of the Antarctic area, whether deriving from the activities of Japanese nationals or otherwise.

$(f)$ Japan renounces all right, title and claim to the Spratly Islands and to the Paracel Islands.

\section{Article 3}

Japan will concur in any proposal of the United States to the United Nations to place under its trusteeship system, with the United States as the sole administering authority, Nansei Shoto south of $29^{\circ}$ north latitude (including the Ryukyu Islands and the Daito Islands), Nanpo Shoto south of Sofu Gan (including the Bonin Islands, Rosario Island and the Volcano Islands) and Parece Vela and Marcus Island. Pending the making of such a proposal and affirmative action thereon, the United States will have the right to exercise all and any powers of administration, legislation and jurisdiction over the territory and inhabitants of these islands, including their territorial waters.

\section{Article 4}

(a) Subject to the provisions of paragraph $(b)$ of this Article, the disposition of property of Japan and of its nationals in the areas referred to in Article 2, and their claims, including debts, against the authorities presently administering such areas and the residents (including juridical persons) thereof, and the disposition in Japan of property of such authorities and residents, and of claims, including debts, of such authorities and residents against. Japan and its nationals, shall be the subject of special arrangements between Japan and such authorities. The property of any of the Allied Powers or its nationals in the areas referred to in Article 2 shall, in so far as this has not already been done, be returned by the administering authority in the condition in which it now exists. (The term nationals whenever used in the present Treaty includes juridical persons.)

(b) Japan recognizes the validity of dispositions of property of Japan and Japanese nationals made by or pursuant to directives of the United States Military Government in any of the areas referred to in Articles 2 and 3.

(c) Japanese-owned submarine cables connecting Japan with territory removed from Japanese control pursuant to the present Treaty shall be equally

1 United Nations, Treaty Series, Vol. 8, p. 189.

No. 1832 
divided, Japan retaining the Japanese terminal and adjoining half of the cable, and the detached territory the remainder of the cable and connecting terminal tacilities.

\section{CHAPTER III}

\section{SECURITY}

\section{Article 5}

(a) Japan accepts the obligations set forth in Article 2 of the Charter of the United Nations, and in particular the obligations

(i) to settle its international disputes by peaceful means in such a manner that international peace and security, and justice, are not endangered ;

(ii) to refrain in its international relations from the threat or use of force against the territorial integrity or political independence of any State or in any other manner inconsistent with the Purposes of the United Nations ;

(iii) to give the United Nations every assistance in any action it takes in accordance with the Charter and to refrain from giving assistance to any State against which the United Nations may take preventive or enforcement action.

(b) The Allied Powers confirm that they will be guided by the principles of Article 2 of the Charter of the United Nations in their relations with Japan.

(c) The Allied Powers for their part recognize that Japan as as overeign nation possesses the inherent right of individual or collective self-defense referred to in Article 51 of the Charter of the United Nations and that Japan may voluntarily enter into collective security arrangements.

\section{Article 6}

(a) All occupation forces of the Allied Powers shall be withdrawn from Japan as soon as possible after the coming into force of the present Treaty, and in any case not later than 90 days thereafter. Nothing in this provision shall, however, prevent the stationing or retention of foreign armed forces in Japanese territory under or in consequence of any bilateral or multilateral agreements which have been or may be made between one or more of the Allied Powers, on the one hand, and Japan on the other.

(b) The provisions of Article 9 of the Potsdam Proclamation of July 26, 1945, dealing with the return of Japanese military forces to their homes, to the extent not already completed, will be carried out.

(c) All Japanese property for which compensation has not already been paid, which was supplied for the use of the occupation forces and which remains in the 
possession of those forces at the time of the coming into force of the present Treaty, shall be returned to the Japanese Government within the same 90 days unless other arrangements are made by mutual agreement.

\section{CHAPTER IV}

\section{Political and economic clauses}

\section{Article 7}

(a) Each of the Allied Powers, within one year after the present Treaty has come into force between it and Japan, will notify Japan which of its prewar bilateral treaties or conventions with Japan it wishes to continue in force or revive, and any treaties or conventions so notified shall continue in force or be revived subject only to such amendments as may be necessary to ensure conformity with the present Treaty. The treaties and conventions so notified shall be considered as having been continued in force or revived three months after the date of notification and shall be registered with the Secretariat of the United Nations. All such treaties and conventions as to which Japan is not so notified shall be regarded as abrogated.

(b) Any notification made under paragraph (a) of this Article may except from the operation or revival of a treaty or convention any territory for the international relations of which the notifying Power is responsible, until three months after the date on which notice is given to Japan that such exception shall cease to apply.

\section{Article 8}

(a) Japan will recognize the full force of all treaties now or hereafter concluded by the Allied Powers for terminating the state of war initiated on September 1, 1939, as well as any other arrangements by the Allied Powers for or in connection with the restoration of peace. Japan also accepts the arrangements made for terminating the former League of Nations and Permanent Court of International Justice.

(b) Japan renounces all such rights and interests as it may derive from being a signatory power of the Conventions of St. Germain-en-Laye of September 10, $1919,{ }^{1}$ and the Straits Agreement of Montreux of July 20, 1936, ${ }^{2}$ and from

${ }^{1}$ League of Nations, Treaty Series, Vol. VII, p. 332.

2 League of Nations, Treaty Series, Vol. CLXXIII, p. 213.

No. 1832 
Article 16 of the Treaty of Peace with Turkey signed at Lausanne on July 24, 1923. 1

(c) Japan renounces all rights, titles and interests acquired under, and is discharged from all obligations resulting from, the Agreement between Germany and the Creditor Powers of January 20, 1930, ${ }^{2}$ and its Annexes, including the Trust Agreement, dated May 17, $1930 ;{ }^{3}$ the Convention of January 20,1930, ${ }^{4}$ respecting the Bank for International Settlements; and the Statutes of the Bank for International Settlements. Japan will notify to the Ministry of Foreign Affairs in Paris within six months of the first coming into force of the present Treaty its renunciation of the rights, title and interests referred to in this paragraph.

\section{Article 9}

Japan will enter promptly into negotiations with the Allied Powers so desiring for the conclusion of bilateral and multilateral agreements providing for the regulation or limitation of fishing and the conservation and development of fisheries on the high seas.

\section{Article 10}

Japan renounces all special rights and interests in China, including all benefits and privileges resulting from the provisions of the final Protocol signed at Peking on September 7, 1901, 5 and all annexes, notes and documents supplementary thereto, and agrees to the abrogation in respect to Japan of the said protocol, annexes, notes and documents.

\section{Article 11}

Japan accepts the judgments of the International Military Tribunal for the Far East and of other Allied War Crimes Courts both within and outside Japan, and will carry out the sentences imposed thereby upon Japanese nationals imprisoned in Japan. The power to grant clemency, to reduce sentences and to parole with respect to such prisoners may not be exercised except on the decision of the Government or Governments which imposed the sentence in each instance, and on the recommendation of Japan. In the case of persons sentenced by the International Military Tribunal for the Far East, such power may not be exercised except on the decision of a majority of the Governments represented on the Tribunal, and on the recommendation of Japan.

\footnotetext{
1 League of Nations, Treaty Series, Vol, XXVIII, p. 11.

2 League of Nations, Treaty Series, Vol. CIV, p. 243.

3 League of Nations, Treaty Series, Vol. CIV, p. 328.

4 League of Nations, Treaty Series, Vol. CIV, p. 441.

- De Martens : Nouveau Recueil généval de Traités, deuxième série, tome XXXII, p. 94. 


\section{Article 12}

(a) Japan declares its readiness promptly to enter into negotiations for the conclusion with each of the Allied Powers of treaties or agreements to place their trading, maritime and other commercial relations on a stable and friendly basis.

(b) Pending the conclusion of the relevant treaty or agreement, Japan will, during a period of four years from the first coming into force of the present Treaty

(1) accord to each of the Allied Powers, its nationals, products and vessels

(i) most-favored-nation treatment with respect to customs duties, charges, restrictions and other regulations on or in connection with the importation and exportation of goods;

(ii) national treatment with respect to shipping, navigation and imported goods, and with respect to natural and juridical persons and their interests-such treatment to include all matters pertaining to the levying and collection of taxes, access to the courts, the making and performance of contracts, rights to property (tangible and intangible), participation in juridical entities constituted under Japanese law, and generally the conduct of all kinds of business and professional activities ;

(2) ensure that external purchases and sales of Japanese state trading enterprises shall be based solely on commercial considerations.

(c) In respect to any matter, however, Japan shall be obliged to accord to an Allied Power national treatment, or most-favored-nation treatment, only to the extent that the Allied Power concerned accords Japan national treatment or mostfavored-nation treatment, as the case may be, in respect of the same matter. The reciprocity envisaged in the foregoing sentence shall be determined, in the case of products, vessels and juridical entities of, and persons domiciled in, any non-metropolitan territory of an Allied Power, and in the case of juridical entities of, and persons domiciled in, any state or province of an Allied Power having a federal government, by reference to the treatment accorded to Japan in such territory, state or province.

(d) In the application of this Article, a discriminatory measure shall not be considered to derogate from the grant of national or most-favored-nation treatment, as the case may be, if such measure is based on an exception customarily provided for in the commercial treaties of the party applying it, or on the need to safeguard that party's external financial position or balance of payments 
(except in respect to shipping and navigation), or on the need to maintain its essential security interests, and provided such measure is proportionate to the circumstances and not applied in an arbitrary or unreasonable manner.

(e) Japan's obligations under this Article shall not be affected by the exercise of any Allied rights under Article 14 of the present Treaty ; nor shall the provisions of this Article be understood as limiting the undertakings assumed by Japan by virtue of Article 15 of the Treaty.

\title{
Article 13
}

(a) Japan will enter into negotiations with any of the Allied Powers, promptly upon the request of such Power or Powers, for the conclusion of bilateral or multilateral agreements relating to international civil air transport.

(b) Pending the conclusion of such agreement or agreements, Japan will, during a period of four years from the first coming into force of the present Treaty, extend to such Power treatment not less favorable with respect to air-traffic rights and privileges than those exercised by any such Powers at the date of such coming into force, and will accord complete equality of opportunity in respect to the operation and development of air services.

(c) Pending its becoming a party to the Convention on International Civil Aviation ${ }^{1}$ in accordance with Article 93 thereof, Japan will give effect to the provisions of that Convention applicable to the international navigation of aircraft, and will give effect to the standards, practices and procedures adopted as annexes to the Convention in accordance with the terms of the Convention.

\author{
CHAPTER V \\ Claims AND PROPERTY
}

Article 14

(a) It is recognized that Japan should pay reparations to the Allied Powers for the damage and suffering caused by it during the war. Nevertheless it is also recognized that the resources of Japan are not presently sufficient, if it is to

1 United Nations, Treaty Series, Vol. 15, p. 295 ; Vol. 26, p. 420 ; Vol. 32, p. 402 ; Vol. 33. p. 352 ; Vol. 44, p. 346 , and Vol. 51, p. 336 .

No. 1832 
maintain a viable economy, to make complete reparation for all such damage and suffering and at the same time meet its other obligations.

Therefore,

1. Japan will promptly enter into negotiations with Allied Powers so desiring, whose present territories were occupied by Japanese forces and damaged by Japan, with a view to assisting to compensate those countries for the cost of repairing the damage done, by making available the services of the Japanese people in production, salvaging and other work for the Allied Powers in question. Such arrangements shall avoid the imposition of additional liabilities on other Allied Powers, and, where the manufacturing of raw materials is called for, they shall be supplied by the Allied Powers in question, so as not to throw any foreign exchange burden upon Japan.

2. (I) Subject to the provisions of sub-paragraph (II) below, each of the Allied Powers shall have the right to seize, retain, liquidate or otherwise dispose of all property, rights and interests of

(a) Japan and Japanese nationals,

(b) persons acting for or on behalf of Japan or Japanese nationals, and

(c) entities owned or controlled by Japan or Japanese nationals,

which on the first coming into force of the present Treaty were subject to its jurisdiction. The property, rights and interests specified in this sub-paragraph shall include those now blocked, vested or in the possession or under the control of enemy property authorities of Allied Powers, which belonged to, or were held or managed on behalf of, any of the persons or entities mentioned in $(a),(b)$ or $(c)$ above at the time such assets came under the controls of such authorities.

(II) The following shall be excepted from the right specified in sub-paragraph (I) above :

(i) property of Japanese natural persons who during the war resided with the permission of the Government concerned in the territory of one of the Allied Powers, other than territory occupied by Japan, except property subjected to restrictions during the war and not released from such restrictions as of the date of the first coming into force of the present Treaty; 
(ii) all real property, furniture and fixtures owned by the Government of Japan and used for diplomatic or consular purposes, and all personal furniture and furnishings and other private property not of an investment nature which was normally necessary for the carrying out of diplomatic and consular functions, owned by Japanese diplomatic and consular personnel ;

(iii) property belonging to religious bodies or private charitable institutions and used exclusively for religious or charitable purposes;

(iv) property, rights and interests which have come within its jurisdiction in consequence of the resumption of trade and financial relations subsequent to September 2, 1945, between the country concerned and Japan, except such as have resulted from transactions contrary to the laws of the Allied Power concerned;

(v) obligations of Japan or Japanese nationals, any right, title or interest in tangible property located in Japan, interests in enterprises organized under the laws of Japan, or any paper evidence thereof ; provided that this exception shall only apply to obligations of Japan and its nationals expressed in Japanese currency.

(III) Property referred to in exceptions (i) through (v) above shall be returned subject to reasonable expenses for its preservation and administration. If any such property has been liquidated the proceeds shall be returned instead.

(IV) The right to seize, retain, liquidate or otherwise dispose of property as provided in sub-paragraph (I) above shall be exercised in accordance with the laws of the Allied Power concerned, and the owner shall have only such rights as may be given him by those laws.

(V) The Allied Powers agree to deal with Japanese trademarks and literary and artistic property rights on a basis as favorable to Japan as circumstances ruling in each country will permit.

(b) Except as otherwise provided in the present Treaty, the Allied Powers waive all reparations claims of the Allied Powers, other claims of the Allied Powers and their nationals arising out of any actions taken by Japan and its nationals in the course of the prosecution of the war, and claims of the Allied Powers for direct military costs of occupation. 


\section{Article 15}

(a) Upon application made within nine months of the coming into force of the present Treaty between Japan and the Allied Power concerned, Japan will, within six months of the date of such application, return the property, tangible and intangible, and all rights or interests of any kind in Japan of each Allied Power and its nationals which was within Japan at any time between December 7, 1941, and September 2, 1945, unless the owner has freely disposed thereof without duress or fraud. Such property shall be returned free of all encumbrances and charges to which it may have become subject because of the war, and without any charges for its return. Property whose return is not applied for by or on behalf of the owner or by his Government within the prescribed period may be disposed of by the Japanese Government as it may determine. In cases where such property was within Japan on December 7, 1941, and cannot be returned or has suffered injury or damage as a result of the war, compensation will be made on terms not less favorable than the terms provided in the draft Allied Powers Property Compensation Law approved by the Japanese Cabinet on July 13, 1951.

(b) With respect to industrial property rights impaired during the war, Japan will continue to accord to the Allied Powers and their nationals benefits no less than those heretofore accorded by Cabinet Orders No. 309 effective September 1, 1949, No. 12 effective January 28, 1950, and No. 9 effective February 1, 1950, all as now amended, provided such nationals have applied for such benefits within the time limits prescribed therein.

(c) (i) Japan acknowledges that the literary and artistic property rights which existed in Japan on December 6, 1941, in respect to the published and unpublished works of the Allied Powers and their nationals have continued in force since that date, and recognizes those rights which have arisen, or but for the war would have arisen, in Japan since that date, by the operation of any conventions and agreements to which Japan was a party on that date, irrespective of whether or not such conventions or agreements were abrogated or suspended upon or since the outbreak of war by the domestic law of Japan or of the Allied Power concerned.

(ii) Without the need for application by the proprietor of the right and without the payment of any fee or compliance with any other formality, the period from December 7, 1941, until the coming into force of the present Treaty between Japan and the Allied Power concerned shall be excluded from the running of the normal term of such rights; and such period, with an additional period of six montlis, shall be excluded from the time within which a literary work must be translated into Japanese in order to obtain translating rights in Japan. 


\section{Article 16}

As an expression of its desire to indemnify those members of the armed forces of the Allied Powers who suffered undue hardships while prisoners of war of Japan, Japan will transfer its assets and those of its nationals in countries which were neutral during the war, or which were at war with any of the Allied Powers, or, at its option, the equivalent of such assets, to the International Committee of the Red Cross which shall liquidate such assets and distribute the resultant fund to appropriate national agencies, for the benefit of former prisoners of war and their families on such basis as it may determine to be equitable. The categories of assets described in Article 14 (a) 2(II) (ii) through (v) of the present Treaty shall be excepted from transfer, as well as assets of Japanese natural persons not residents of Japan on the first coming into force of the Treaty. It is equally understood that the transfer provision of this Article has no application to the 19,770 shares in the Bank for International Settlements presently owned by Japanese financial institutions.

\section{Article 1 'y}

(a) Upon the request of any of the Allied Powers, the Japanese Government shall review and revise in conformity with international law any decision or order of the Japanese Prize Courts in cases involving ownership rights of nationals of that Allied Power and shall supply copies of all documents comprising the records of these cases, including the decisions taken and orders issued. In any case in which such review or revision shows that restoration is due, the provisions of Article 15 shall apply to the property concerned.

(b) The Japanese Government shall take the necessary measures to enable nationals of any of the Allied Powers at any time within one year from the coming into force of the present Treaty between Japan and the Allied Power concerned to submit to the appropriate Japanese authorities for review any judgment given by a Japanese court between December 7, 1941, and such coming into force, in any proceedings in which any such national was unable to make adequate presentation of his case either as plaintiff or defendant. The Japanese Government shall provide that, where the national has suffered injury by reason of any such judgment, he shall be restored in the position in which he was before the judgment was given or shall be afforded such relief as may be just and equitable in the circumstances.

\section{Article 18}

(a) It is recognized that the intervention of the state of war has not affected the obligation to pay pecuniary debts arising out of obligations and contracts 
(including those in respect of bonds) which existed and rights which were acquired before the existence of a state of war, and which are due by the Government or nationals of Japan to the Government or nationals of one of the Allied Powers, or are due by the Government or nationals of one of the Allied Powers to the Government or nationals of Japan. The intervention of a state of war shall equally not be regarded as affecting the obligation to consider on their merits claims for loss or damage to property or for personal injury or death which arose before the existence of a state of war, and which may be presented or re-presented by the Government of one of the Allied Powers to the Government of Japan, or by the Government of Japan to any of the Governments of the Allied Powers. The provisions of this paragraph are without prejudice to the rights conferred by Article 14.

(b) Japan affirms its liability for the prewar external debt of the Japanese State and for debts of corporate bodies subsequently declared to be liabilities of the Japanese State, and expresses its intention to enter into negotiations at an early date with its creditors with respect to the resumption of payments on those debts ; to encourage negotiations in respect to other prewar claims and obligations ; and to facilitate the transfer of sums accordingly.

\section{Article 19}

(a) Japan waives all claims of Japan and its nationals against the Allied Powers and their nationals arising out of the war or out of actions taken because of the existence of a state of war, and waives all claims arising from the presence, operations or actions of forces or authorities of any of the Allied Powers in Japanese territory prior to the coming into force of the present Treaty.

(b) The foregoing waiver includes any claims arising out of actions taken by any of the Allied Powers with respect to Japanese ships between September 1, 1939, and the coming into force of the present Treaty, as well as any claims and debts arising in respect to Japanese prisoners of war and civilian internees in the hands of the Allied Powers, but does not include Japanese claims specifically recognized in the laws of any Allied Power enacted since September 2, 1945.

(c) Subject to reciprocal renunciation, the Japanese Government also renounces all claims (including debts) against Germany and German nationals on behalf of the Japanese Government and Japanese nationals, including intergovernmental claims and claims for loss or damage sustained during the war, but excepting (a) claims in respect of contracts entered into and rights acquired before September 1, 1939, and (b) claims arising out of trade and financial relations 
between Japan and Germany after September 2, 1945. Such renunciation shall not prejudice actions taken in accordance with Articles 16 and 20 of the present Treaty.

(d) Japan recognizes the validity of all acts and omissions done during the period of occupation under or in consequence of directives of the occupation authorities or authorized by Japanese law at that time, and will take no action subjecting Allied nationals to civil or criminal liability arising out of such acts or omissions.

\section{Article 20}

Japan will take all necessary measures to ensure such disposition of German assets in Japan as has been or may be determined by those powers entitled under the Protocol of the proceedings of the Berlin Conference of 1945 to dispose of those assets, and pending the final disposition of such assets will be responsible for the conservation and administration thereof.

\section{Article 21}

Notwithstanding the provisions of Article 25 of the present Treaty, China shall be entitled to the benefits of Articles 10 and 14(a)2 ; and Korea to the benefits of Articles 2, 4, 9 and 12 of the present Treaty.

\section{CHAPTER VI \\ SetTlement of Disputes}

\section{Article 22}

If in the opinion of any Party to the present Treaty there has arisen a dispute concerning the interpretation or execution of the Treaty, which is not settled by reference to a special claims tribunal or by other agreed means, the dispute shall, at the request of any party thereto, be referred for decision to the International Court of Justice. Japan and those Allied Powers which are not already parties to the Statute of the International Court of Justice ${ }^{1}$ will deposit with the Registrar of the Court, at the time of their respective ratifications of the present Treaty, and in conformity with the resolution of the United Nations Security Council, dated October 15, 1946, ${ }^{2}$ a general declaration accepting the jurisdiction, without special agreement, of the Court generally in respect to all disputes of the character referred to in this Article.

\footnotetext{
League of Nations, Treaty Series, Vol. VI, p. 390.

2 Official Records of the Security Council, first year, second series, No. 19, p. 467. 


\section{CHAPTER VII}

\section{Final Clauses}

\section{Article 23}

(a) The present Treaty shall be ratified by the States which sign it, including Japan, and will come into force for all the States which have then ratified it, when instruments of ratification have been deposited by Japan and by a majority, including the United States of America as the principal occupying Power, of the following States, namely Australia, Canada, Ceylon, France, Indonesia, the Kingdom of the Netherlands, New Zealand, Pakistan, the Republic of the Philippines, the United Kingdom of Great Britain and Northern Ireland, and the United States of America. The present Treaty shall come into force for each State which subsequently ratifies it, on the date of the deposit of its instrument of ratification.

(b) If the Treaty has not come into force within nine months after the date of the deposit of Japan's ratification, any State which has ratified it may bring the Treaty into force between itself and Japan by a notification to that effect given to the Governments of Japan and the United States of America not later than three years after the date of deposit of Japan's ratification.

\section{Article 24}

All instruments of ratification shall be deposited with the Government of the United States of America which will notify all the signatory States of each such deposit, of the date of the coming into force of the Treaty under paragraph $(a)$ of Article 23, and of any notifications made under paragraph $(b)$ of Article 23.

\section{Article 25}

For the purposes of the present Treaty the Allied Powers shall be the States at war with Japan, or any State which previously formed a part of the territory of a State named in Article 23, provided that in each case the State concerned has signed and ratified the Treaty. Subject to the provisions of Article 21, the present Treaty shall not confer any rights, titles or benefits on any State which is not an Allied Power as herein defined; nor shall any right, title or interest of Japan be deemed to be diminished or prejudiced by any provision of the Treaty in favor of a State which is not an Allied Power as so defined. 


\section{Article 26}

Japan will be prepared to conclude with any State which signed or adhered to the United Nations Declaration of January $1,1942,{ }^{1}$ and which is at war with Japan, or with any State which previously formed a part of the territory of a State named in Article 23, which is not a signatory of the present Treaty, a bilateral Treaty of Peace on the same or substantially the same terms as are provided for in the present Treaty, but this obligation on the part of Japan will expire three years after the first coming into force of the present Treaty. Should Japan make a peace settlement or war claims settlement with any State granting that State greater advantages than those provided by the present Treaty, those same advantages shall be extended to the parties to the present Treaty.

\section{Article 27}

The present Treaty shall be deposited in the archives of the Government of the United States of America which shall furnish each signatory State with a certified copy thereof.

1 League of Nations, Treaty Series, Vol. CCIV, p. 381. 
IN FAITH WHEREOF the undersigned Plenipotentiaries have signed the present Treaty.

Done at the city of San Francisco this eighth day of September 1951, in the English, French, and Spanish languages, all being equally authentic, and in the Japanese language.

EN FOr DE Quor, les Plénipotentiaires soussignés ont apposé leur signature au bas du présent Traité.

Fart en la ville de San-Francisco, ce huitième jour du mois de septembre 1951, en langues anglaise, française et espagnole, toutes faisant également foi, ainsi qu'en langue japonaise.

EN FE DE LO CUAL los infrascritos Plenipotenciarios firman el presente Tratado.

Hecho en la ciudad de San Francisco, el ocho de Septiembre de 1951, en los idiomas inglés, francés y español, todos de igual autenticidad, y en el idioma japonés.

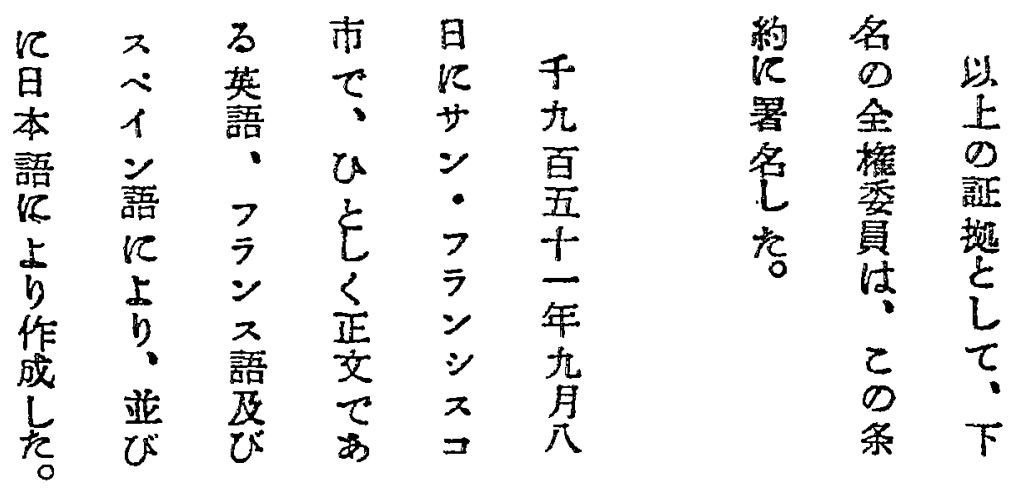


126

United Nations - Treaty Series

1952

FOR ARGENTINA:

POUR L'ARGENTINE:

POR LA ARGENTINA:

フルせ゚ンティンのために

Hividito 7 lar

FOR AUSTRA LIA:

POUR L'AUSTRALIE:

POR AUSTRA LIA:

tーストラリ丁のれめに

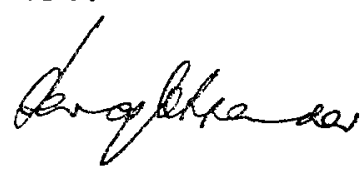

FOR THE KINGDOM OF BELGIUM:

POUR LE ROYAUME DE BELGIQUE:

POR EL REINO DE BELGICA:

ベッ゙ー王国のために

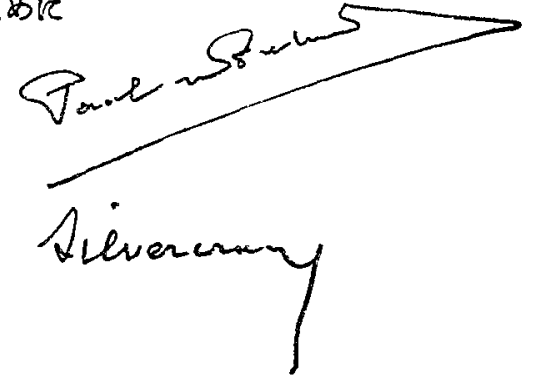

FOR BOITVIA:

POUR LA BOLIVIE:

POR BOLIVIA:

ボリヴアのために

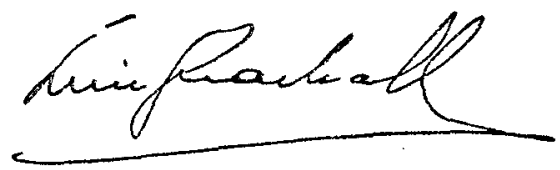

No. 1832 
1952

Nations Unies - Recueil des Traités

127

FOR BRAZIL:

POUR LE BRESIL:

POR EL BRASIL:

ブラジルのために

A. de melention

FOR CAMBODIA:

POUR LE CAMBODGE:

POR CAMBODGE:

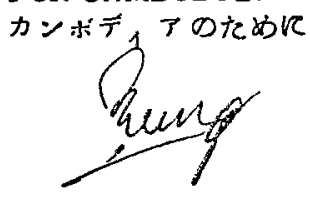

FOR CANADA:

ROUR LE CANADA:

POR EL CANADA:

カナタのため

Gatir B fewn

FOR CEYLON:

POUR CEYLAN:

POR CEILAN:

セイロンのために

gregnswuature

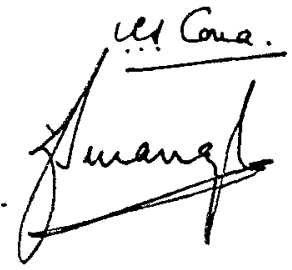

N० 1832 
\begin{tabular}{lll}
\hline 128 & United Nations - Treaty Series & 1952 \\
\hline
\end{tabular}

FOR CHILE:

POUR LE CHIN:

POE CHILE:

チリのために

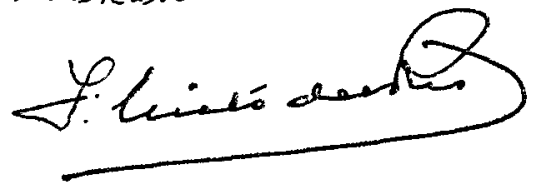

FOR COLOMBIA:

POUR LA COLOMBIA:
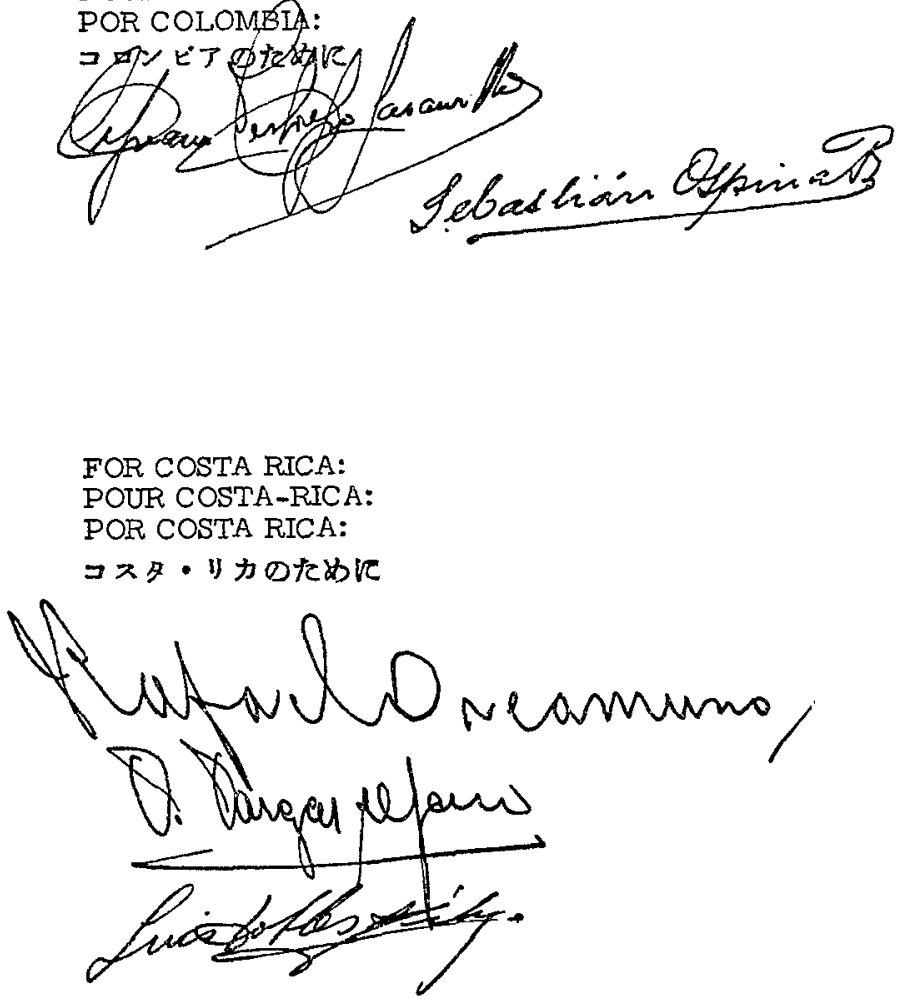

No. 1832 
1952

Nations Unies - Recueil des Traités

129

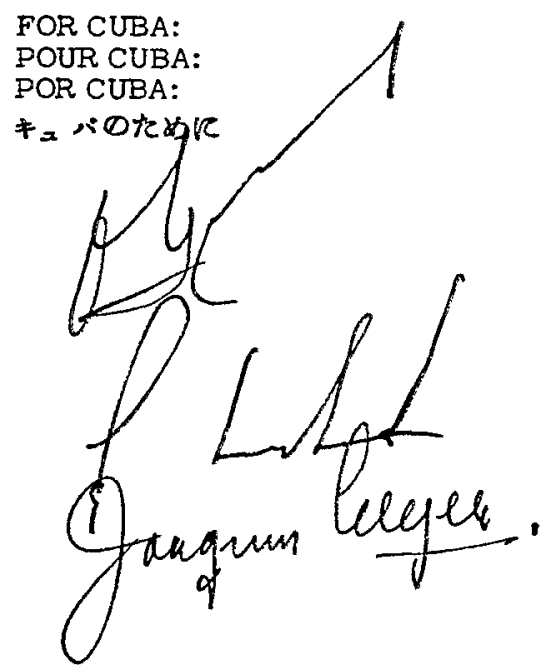

FOR THE DOMIINICAN REPUBLIC:

POUR LA REPUBLIUE DOMINICAINE:

POR LA RE耳UBLICA DOMINICANA:

トミニカ却和圂のために

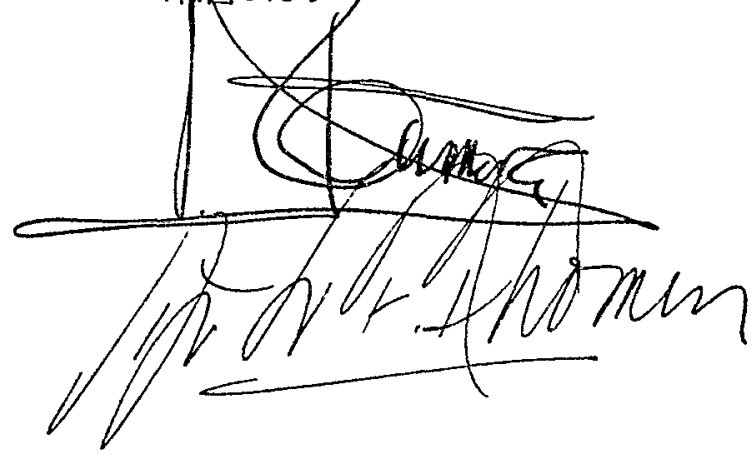

FOR ECUADOR:

POUR L'EQUATEUR:

POR EL ECUADOR:

エクアドルのた的に

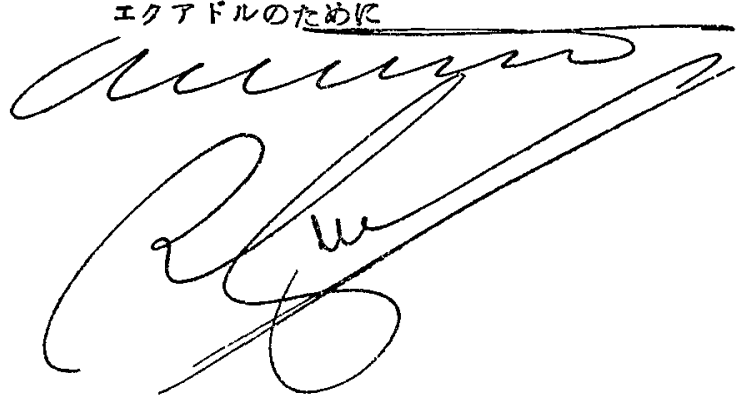

No 1832 
130

United Nations - Treaty Series

1952

FOR EGYPT:

POUR L'EGYPTE:

POR EGIPTO:

エシプトのたい

Komb. 4.Gahem Th

FOR EL SA LVADOR:

POUR LE SALVADOR:

POR EL SALVADOR: サルヴードルのために
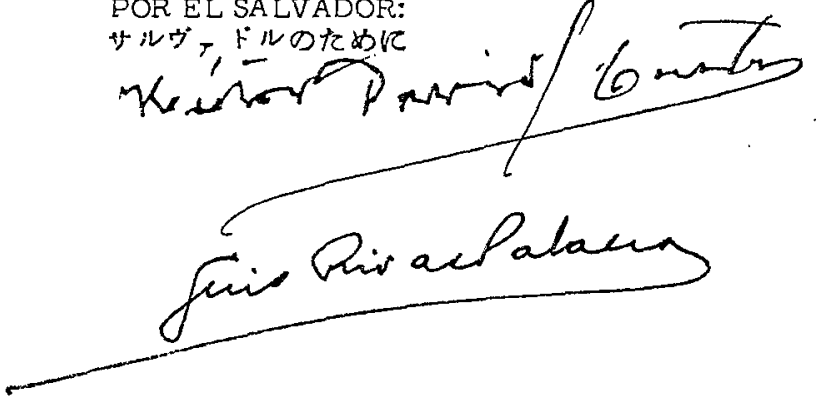

FOR ETHIOPIA:

POUR L'ETHIOPIE:

POR ETIOPIA:

エテ

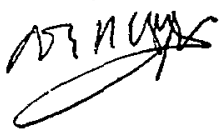

FOR FRANCE:

POUR LA FRANCE:

POR FRANCIA:

フランスのために

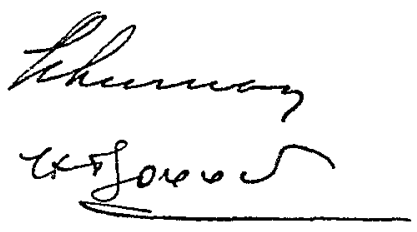

Paml einh Nygion

No. 1832 
1952

Nations Unies - Recueil des Traités

131

FOR GREECE:

POUR LA GRECE:

POR GRECIA:

ギリシャのために

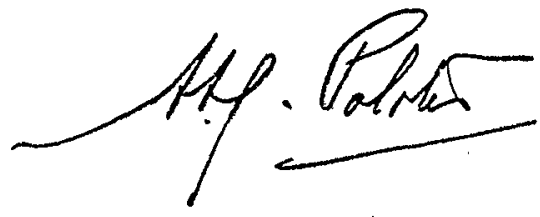

FOR GUATEMALA:

POUR LE GUATEMALA

POR GUATEMALA:

グァテマラのために

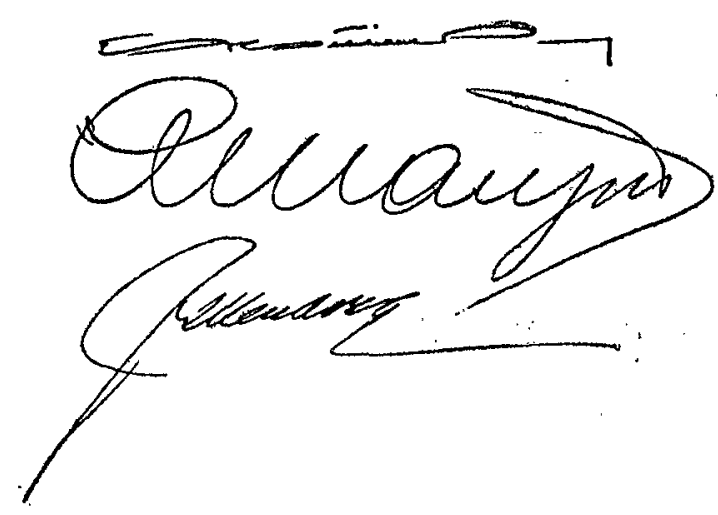

FOR HAITI:

POUR HAITI:

POR HAITI:

ハイティのため

gust arague

No 1832

10 


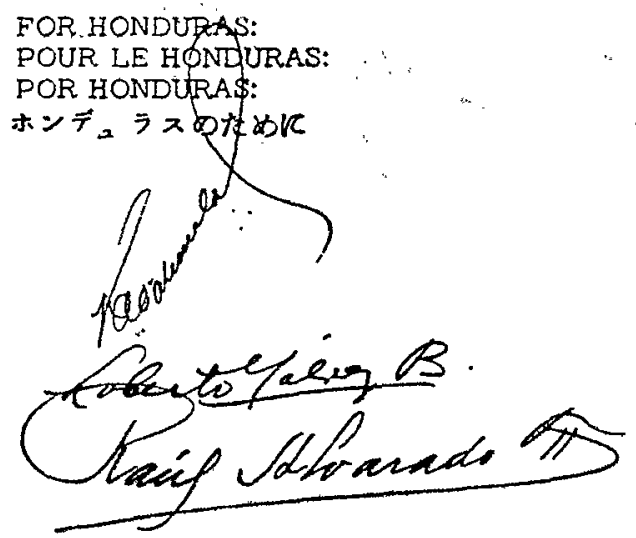

FOR INDONESIA:

POUR L'INDONESIE:

POR INDONESIA:

インドネシフのために

FOR IRAN:

POUR L'IRAN:

POR IRAN:

イランのために

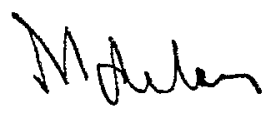

FOR IRAQ:

POUR I'IRAK:

POR IRAK:

イラークのために

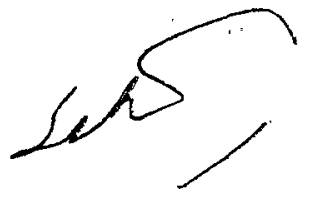


1952

Nations Unies - Recueil des Traités

133

FOR LAOS:

POUR LE LAOS:

POR LAOS:

ラォスのために

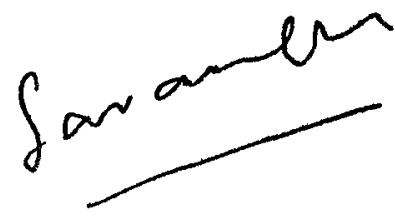

FOR LEBANON:

POUR LE LIBAN:

POR EL LIBANO:

レハノンのために

charles wois

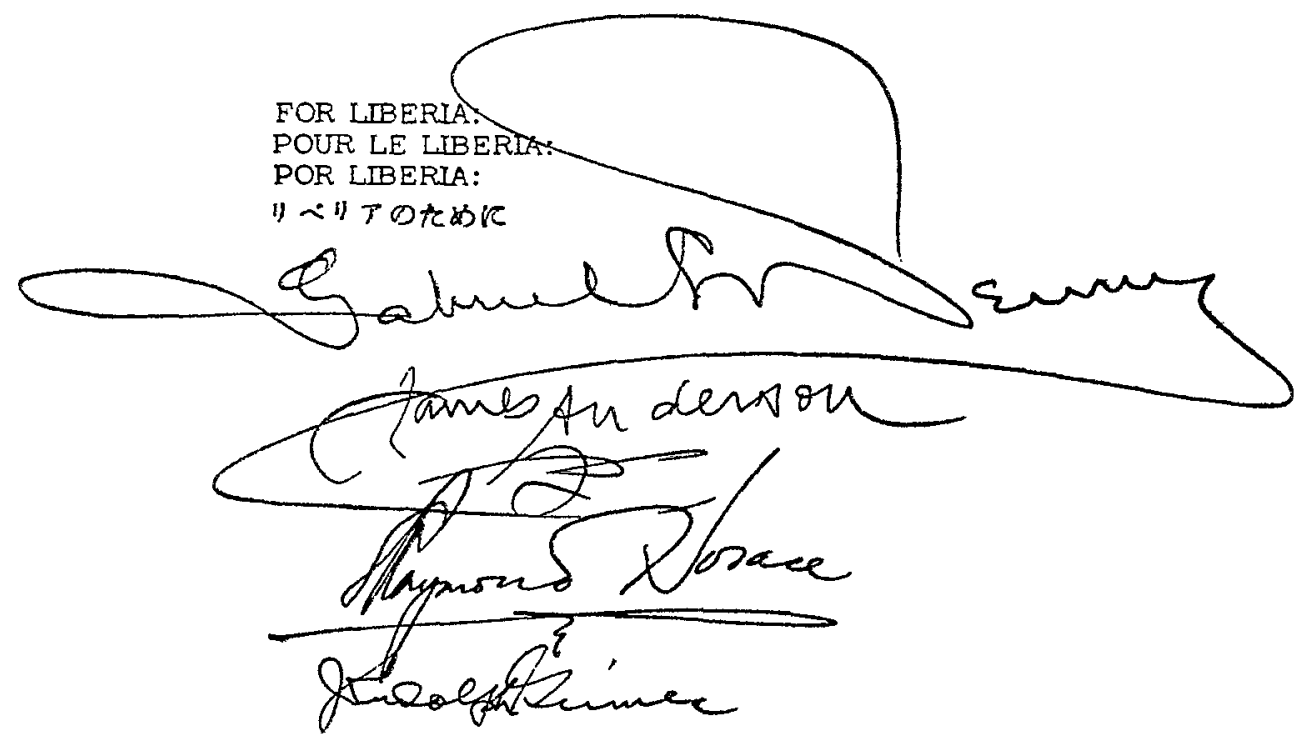

No 1832 
FOR THE GRAND DUCHY OF LUXEMBOURG: POUR LE GRAND DUCHE DE LUXEMBOURG: POR EL GRAN DUCADO DE LUXEMBURGO:

ルクヒンブルグ大公国のために

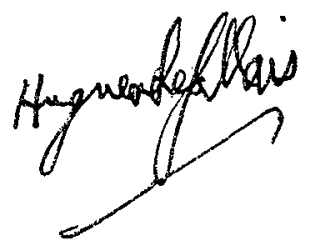

FOR MEXICO:

POUR LE MEXIQUE:

POR MEXICO:

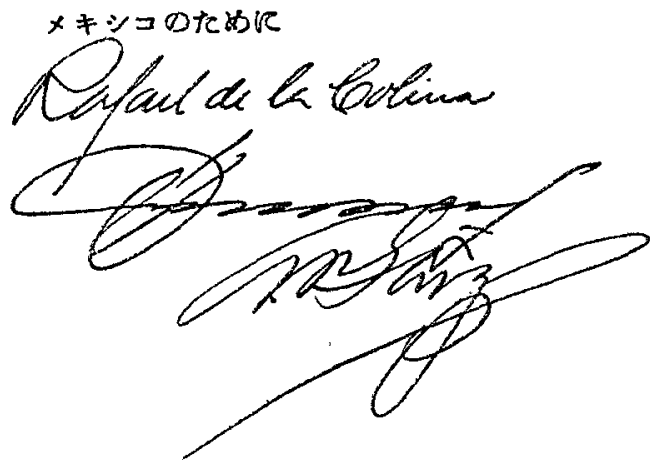

FOR THE KINGDOM OF THE NETHERLANDS:

POUR LE ROYAUME DES PAYS-BAS:

POR EL REINO DE HOLANDA:

ォラン.゙゙壬国のために
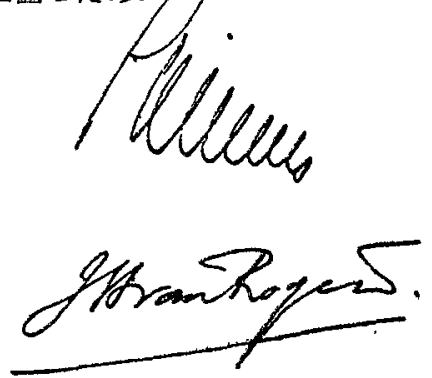
1952

Nations Unies - Recueil des Traités

135

FOR NEW ZEALAND:

POUR LA NOUVELLE-ZELANDE:

POR NUEVA ZELANDIA:

ニュー・ジーランドのために

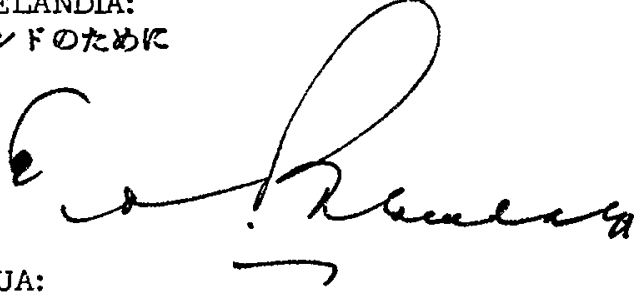

FOR NICARAGUA:

POUR LE NICARAGUA:

POF NICARAGUA:

ニカラグ、のために

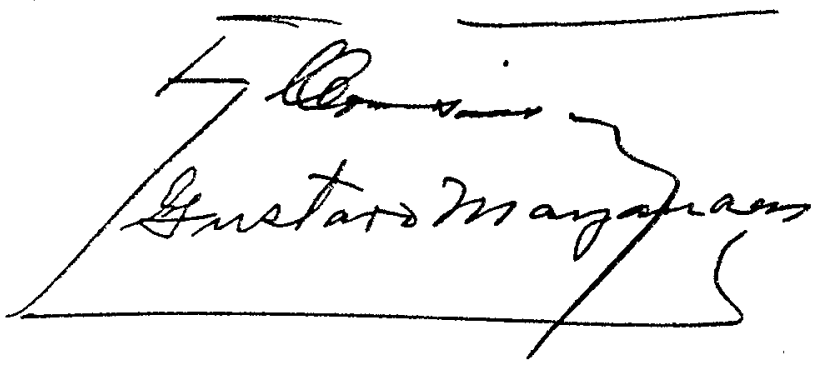

FOR THE KINGDOM OF NORWAY:

POUR LE ROYAUME DE NORVEGE:

POR EL REINO DE NORUEGA:

ノールゥェー王国のために

Wituidm Hruaten Hopentien

FOR PAKISTAN:

POUR LE PAKISTAN:

POR PAKISTAN:

パキスタンのために

3 afunle arhan

No 1832 
\begin{tabular}{lll}
\hline 136 & United Nations - Treaty Series & 1952 \\
\hline
\end{tabular}

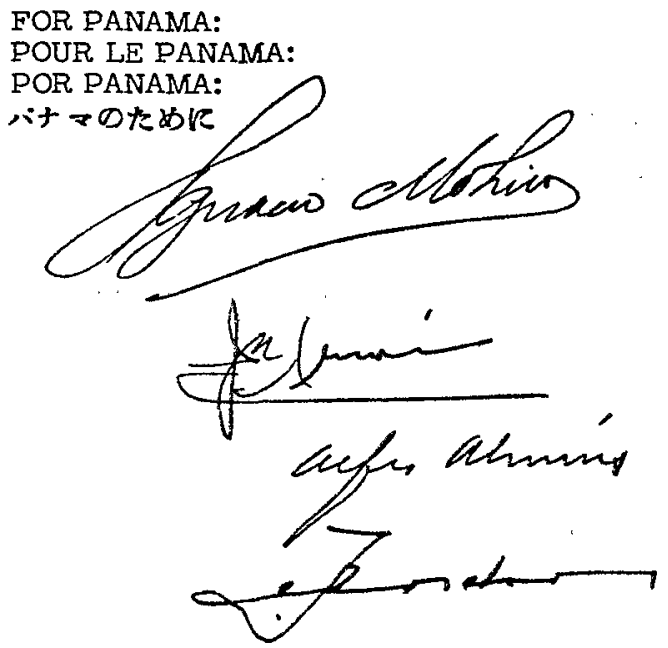

FOR PARAGUAY:

POUR LE PARAGUAY:

DOR PARAGUAY:

ハラグォイのために

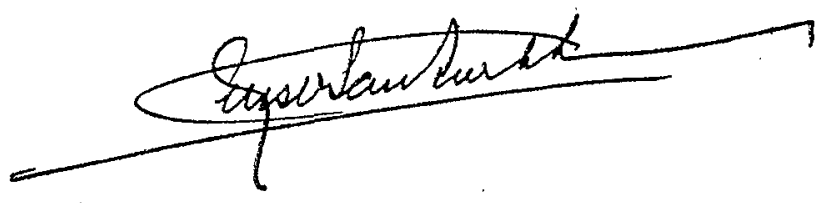

FOR PERU:

POUR LE PERU:

DOR PERU:

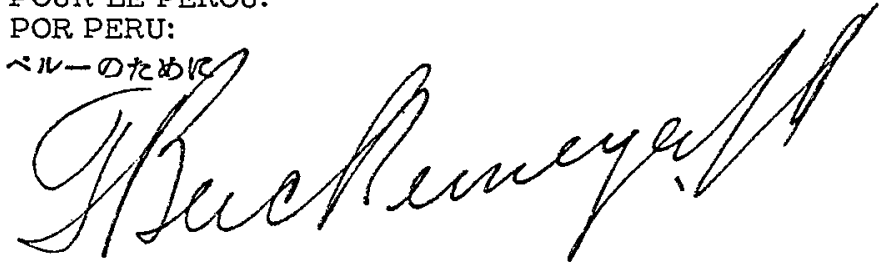

No. 1832 
FOR THE REPUBLIC OF THE PHILIPPINES: POUR LA REPUBLIQUE DES PHILIPPINES: POR LA REPUBLICA DE FILTPINAS:

フィリピン共和国のために

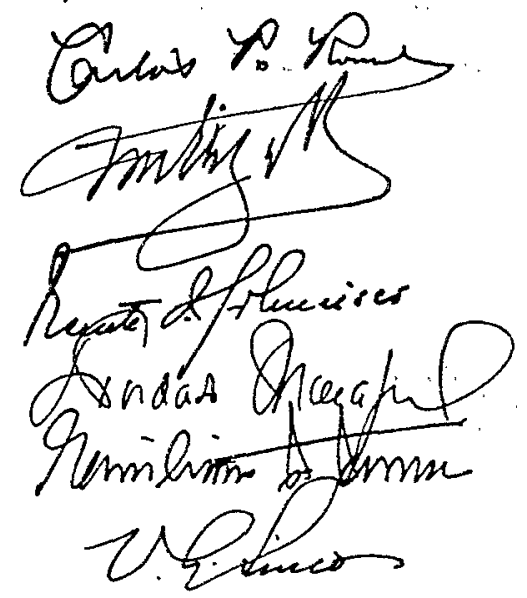

FOR SAUDI ARABIA:

POUR L'ARABIE SAOUDITE:

POR ARABIA SAUDITA:

サウデ

FOR SYRIA:

POUR LA SYRIE:

POR SIRIA:

シリ丁のために

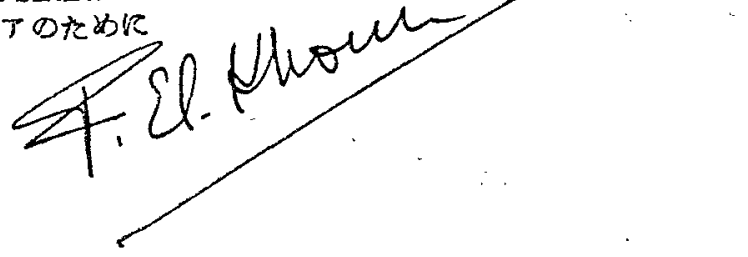


138

United Nations - Treaty Series.

1952

FOR THE REPUBLIC OF TURKEY:

POUR LA REPUBLIQUE DE TURQUIE:

POR LA REPUBLICA DE TURQUIA:

トルコ共和国のたかに

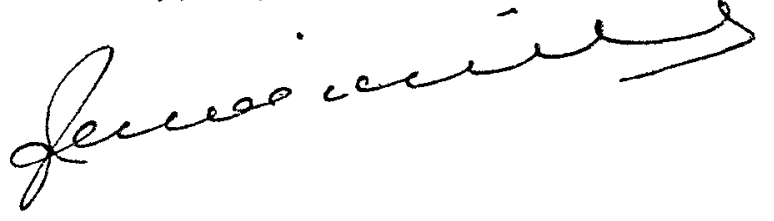

FOR THE UNION OF SOUTH AFRICA:

POUR L'UNION SUD-AFRICAINE:

POR LA UNION SUDAFRICANA:

南フフリカ連那のために

erppoort

FOR THE UNITED KINGDOM OF GREAT BRITAIN AND NORTHERN IRE LAND:

POUR LE ROYAUME-UNI DE GRANDE-BRETAGNE ET D'RLANDE DU NORD:

POR EL REINO UNIDO DE LA GRAN BRETANA E IRLANDA DEL NORTE:

グレート・ブリテン及び北部フィルランド連合王

Henurr Momary

Kunmin Goungers

Dloir Fants

No 1832 
1952

Nations Unies - Recueil des Traités

139

FOR THE UNITED STATES OF AMERICA:

POUR LES ETATS-UNIS D'AMERIQUE:

POR LOS ESTADOS UNIDOS DE AMERICA:

アメリカ合察国层なに

chant ifherson

goln g. Spartmon

FOR URUGUAY:

POUR L'URUGUAY:

POR EL URUGUAY:

ウルグフイのた

fréce. Lura

FOR VENEZUELA:

POUR LE VENEZUELA:

POR VENEZUELA:

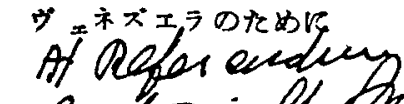

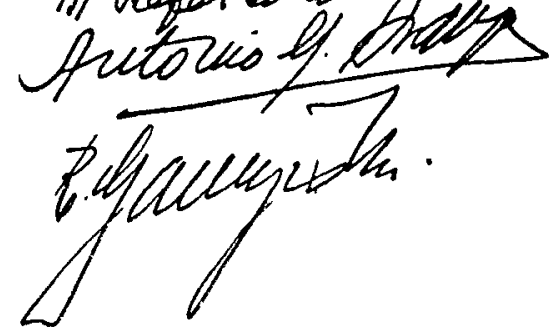

No 1832 
140

United Nations - Treaty Series

1952

FOR VIET NAM:

POUR LE VIET-NAM:

POR VIET-NAM:

サィェトナムのために

?. $>$

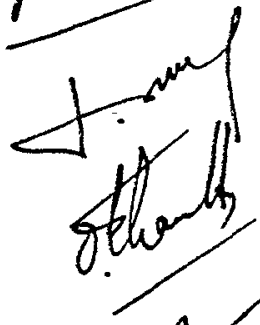

FOR JAPAN:
POUR LE JAPON:
POR EL JAPON:

日本国のため化

Shiger Yooluda

Itagoto gkeda

Gizo. Gor hech i

Avo Hotliginnd

Thuregoabi Solengawos

Anivo Voluinadus

No. 1832 
Note by the Secretariat : According to information supplied by the Government of the United States of America, the signatures reproduced in facsimile on the preceding pages are those of the following plenipotentiaries :

For Argentina :

For Australia :

For Belgium :

For Bolivia :

For Brazil :
A. de Mello-Franco

Carlos Martins

For Cambodia :

For Canada :

\section{Percy C. SpEnder}

Paul van Zeeland

SILVERCRUYS

\section{Luis Guachalla}

\section{Pour le Brésil :}

\section{Pour le Cambodge :}

\section{Phileng}

$$
\text { Pour le Canada : }
$$

Lester B; PEARson

R. W. MAYHEW

For Ceylon :

$$
\text { Pour Ceylan : }
$$
J. R. JAYEWARDENE
G. C. S. COREA
R. G. Senanayake

For Chile :

Pour le Chili :

F. Nieto dét' Rfo

For Colombia :

Pour la Colombie :

Ciptiano Restrepo Jaramillo

Sebastián Ospina

For Costa Rica :
Pour Costa-Rica :

J. Rafael Oreamuno

V. VARgAS

Luis Dobles SÁNchez 
For Cuba :

Pour Cuba :

O. GANS

L. MACHADO

Joaquín MEYER

For the Dominican Republic:

Pour la République Dominicaine :

V. ORDÓNEZ

Luis F. THOMEN

For Ecuador :

Pour l'Équateur :

A. Quevedo

R. G. VAIENzUEla

For Egypt :

Pour l'Egypte :

Kamil A. Rafim

For El Salvador :

Pour le Salvador :

Héctor David Castro

Luis Rivas Palacios

For Ethiopia :

Pour l'Ethiopie :

Men Yayehirad

For France :

Pour la France :

SCHUMAN

H. BONNET

Paul-Emile Naggiar

For Greece :

Pour la Grece :

A. G. Politis

For Guatemala :

Pour le Guatemala :

E. Castimlo A.

A. M. Orellana

J. Mendoza

For Haiti :

Pour Haiti :

Jacques N. IfEGER

Gust. Laraque

For Honduras :

Pour le Honduras :

J. E. Valenzuela

Roberto Gálvez B.

Raúl Alvarado T.

No. 1832 
For Indonesia :

Pour l'Indonésie :

\section{Ahmad Sưbardjo}

For Iran :

\section{Pour l'Iran :}

A." G. ARdaitan

For Iraq :

Pour l'Irak :

A. I. BAKR

For Laos :

Pour le Laos :

SAVANG

For Lebanon :

Pour le Liban :

Charles MaLIK

For Liberia :

Pour le Libéria :

Gabriel L. DENNIS

James ANDERSON

Raymond Horace

J. Rudolph Grimes

For the Grand Duchy of Luxembourg: $\quad$ Pour le Grand-Duché de Luxembourg :

Hugues Le Gallats

For Mexico :

Pour le Mexique :

Rafael dE LA Colina

Gustavo Dfaz ORDAZ

A. P. GASGA

For the Netherlands :

Pour les Pays-Bas :

D. U. STIKKER

J. H. vaN ROIJEN

For New Zealand :

Pour la Nouvelle-Zélande:

C. Berendsen

For Nicaragua :

Pour le Nicaragua :

G. Sevilla Sacasa

Gustavo Manzanares

For Norway :

Pour la. Norvège :

Wilhelm Munthe Morgenstierne 
For Pakistan :

Pour le Pakistan :

Zafrulla Khan

For Panama :

Pour le Panama :

Ignacio MoLINo

José A. Remon

Alfredo Alemín

J. Cordovez

For Paraguay :

Pour le Paraguay:

Luis Oscar BoETrNeR

For Peru :

Pour le Pérou :

F. BERCKMEYER

For the Republic of the Philippines:

Pour la République des Philippines :

Carlos P. Rómuio

J. M. EIIZALDE

Vicente Francisco

Diosdado Macapagal

Emiliano T. TIRoNA

V. G. Sinco

For Saudi Arabia :

Pour l'Arabie saoudite :

Asad AL-FAQIH

For Syria :

Pour la Syrie :

F. EI-KHoURI

For Turkey :

Pour la Turquie :

Feridun C. ERkIN

For the Union of South Africa :

Pour l'Union Sud-Africaine :

G. P. Jooste

For the United Kingdom of Great Britain and Northern Ireland :

Pour le Royaume-Uni de GrandeBretagne et d'Irlande du Nord :

Herbert MORRISON

Kenneth YouNGER

Oliver Franks

For the United States of America :

Pour les Etats-Unis d'Amérique :

Dean Acheson

John Foster Dulles

Alexander WILEy

John J. Sparkman

No. 1832 
For Uruguay :

For Venezuela :

For Viet-Nam :

For Japan :
Pour l'Uruguay :

José A. Mora

Pour le Venezuela :

Antonio M. Araujo

R. Gallegos M.

Pour le Viet-Nam :

T. V. Huv

T. VINH

D. Thanh

Buu KINH

Pour le Japon :

Shigeru Yoshida

Hayato IKEDA

Gizo Tomabechi

Niro Hoshijima

Muneyoshi Tokugawa

Hisato IcHIMADA 


\section{DEC LARATION}

With respect to the Treaty of Peace ${ }^{1}$ signed this day, the Government of Japan makes the following Declaration :

1. Except as otherwise provided in the said Treaty of Peace, Japan recognizes the full force of all presently effective multilateral international instruments to which Japan was a party on September 1, 1939, and declares that it will, on the first coming into force of the said Treaty, resume all its rights and obligations under those instruments. Where, however, participation in any instrument involves membership in an international organization of which Japan ceased to be a member on or after September 1, 1939, the provisions of the present paragraph shall be dependent on Japan's readmission to membership in the organization concerned.

2. It is the intention of the Japanese Government formally to accede to the following international instruments within the shortest practicable time, not to exceed one year from the first coming into force of the Treaty of Peace :

(1) Protocol ${ }^{2}$ opened for signature at Lake Success on December 11, 1946, amending the agreements, conventions and protocols on narcotic drugs of January 23, 1912, February 11, 1925, February 19, 1925, July 13, 1931, November 27, 1931, and June 26, 1936 ;

(2) Protocol ${ }^{3}$ opened for signature at Paris on November 19, 1948, bringing under international control drugs outside the scope of the convention of July 13, 1931, for limiting the manufacture and regulating the distribution of narcotic drugs, as amended by the protocol signed at Lake Success on December 11, 1946;

(3) International Convention on the Execution of Foreign Arbitral Awards signed at Geneva on September 26, 1927 ;

1 See p. 45 of this volume.

2 United Nations, Treaty Series, Vol. 12 , pp. 179 and 418 to 420 ; Vol. 14, p. 492 ; Vol. 15 , p. 446 ; Vol. 18 , p. 385 ; Vol. 19 , p. 328 ; Vol. 26 , p. 398 ; Vol. 27 , p. 401 ; Vol. 31 , p. 479 ; Vol. 42, p. 355 ; Vol. 43, p. 338 ; Vol. 51, p. 322 ; Vol. 53, p. 418; Vol. 54, p. 384 ; Vol. 71, p. 304 ; Vol. 73, p. 244 ; Vol. 88, p. 426 ; Vol. 90, p. 322 ; Vol. 104, p. 342 ; Vol. 121 , p. 326 ; Vol. 126 , p. 347 ; Vol. 131, p. 307 , and Vol. 132.

3 United Nations, Treaty Series, Vol. 44, p. 277 ; Vol. 45, p. 332 ; Vol. 46, p. 367 ; Vol. 48, p. 310 ; Vol. 54 , p. 408 ; Vol. 67 , p. 352 ; Vol. 68 , p. 278 ; Vol. 71 , p. 325 ; Vol. 73 , p. 271 ; Vol. 76, p. 277 ; Vol. 81, p. 333 ; Vol. 110, p. 315 ; Vol. 128, p. 298, and Vol. 131 , p. 315.

4 League of Nations, Treaty Series, Vol. XCII, p. 301 ; Vol. XCVI, p. 205 ; Vol. C, p. 259 ; Vol. CIV, p. 526 ; Vol. CVII, p. 528 ; Vol. CXI, p. 414 ; Vol. CXVII, p. 303 ; Vol. CXXX, p. 457 ; Vol. CLVI, p. 210 ; Vol. CLXXXI, p. 389 ; Vol. CLXXXV, p. 391 ; Vol. CXCIII, p. 269 ; and United Nations, Treaty Series, Vol. 122, p. 346. 
(4) International Convention ${ }^{1}$ relating to Economic Statistics with protocol signed at Geneva on December 14, 1928, and Protocol ${ }^{2}$ amending the International Convention of 1928 relating to Economic Statistics signed Paris on December 9, 1948 ;

(5) International Convention ${ }^{3}$ relating to the Simplification of Customs Formalities, with protocol of signature, signed at Geneva on November 3, 1923 ;

(6) Agreement 4 of Madrid of April 14, 1891, for the Prevention of False Indications of Origin of Goods, as revised at Washington on June 2, 1911, at The Hague on November 6, 1925, and at London on June 2, 1934 ;

(7) Convention ${ }^{5}$ for the Unification of Certain Rules relating to International Transportation by Air, and additional protocol, signed at Warsaw on October 12, 1929 ;

(8) Convention on Safety of Life at Sea opened for signature at London on June 10, 1948;

(9) Geneva conventions 6, 7, 8, 9 of August 12, 1949, for the protection of war victims.

3. It is equally the intention of the Japanese Government, within six months of the first coming into force of the Treaty of Peace, to apply for Japan's admission

1 League of Nations, Treaty Series, Vol. CX, p. 171 ; Vol. CXVII, p. 330 ; Vol. CXXII, p. 366 ; Vol. CXXVI, p. 454 ; Vol. CXXX, p. 463 ; Vol. CXXXIV, p. 427 ; Vol. CLVI, p. 222 ; Vol. CIXXXI, p. 392 ; Vol. CIXXXV, p. 395 ; Vol. CLXXXIX, p. 466 ; and United Nations, Treaty Series, Vol. 54, p. 411.

${ }^{2}$ United Nations, Treaty Series, Vol. 20, p. 229 ; Vol. 21 , p. 336 ; Vol. 24 , p. 321 ; Vol. 26 , p. 417 ; Vol. 30 , p. 351 ; Vol. 34 , p. 424 ; Vol. 42, p. 359 ; Vol. 44, p. 340 ; Vol. 51, p. 329 , and Vol. 122 , p. 334 .

3 League of Nations, Treaty Series, Vol. XXX, p. 371 ; Vol. XXXV, p. 325 ; Vol. XXXIX, p. 208 ; Vol. XLV, p. 140 ; Vol. L, p. 161 ; Vol. LIV, p. 398 ; Vol. LIX, p. 365 ; Vol. LXIX, p. 79 ; Vol. IXXXIII, p. 394 ; Vol. LXXXVIII, p. 319 ; Vol. XCII, p. 370; Vol. CXI, p. 404; Vol. CXXXIV, p. 401 ; Vol. CXIVII, p. 322, and Vol. CXCVI, p. 410.

4 League of Nations, Treaty Series, Vol. CXCII, p. 9, and Vol, CCIV, p. 469.

5 League of Nations, Treaty Series, Vol. CXXXVII, p. 11 ; Vol. CXLII, p. 393 ; Vol. CXIVII, p. 355 ; Vol. CLVI, p. 258 ; Vol. CLX, p. 418 ; Vol. CLXIV, p. 395 ; Vol. CLXXII, p. 425 ; Vol. CLXXVII, p. 420 ; Vol. CLXXXI, p. 397 ; Vol. CLXXXV, p. 406 ; Vol. CXCIII, p. 273, and Vol. CXCVI, p. 422.

- Geneva Convention for the amelioration of the condition of the wounded and sick in armed forces in the field of 12 August, 1949: United Nations, Trealy Series, Vol. 75, p. 31; Vol. 78, p. 365 ; Vol. 84, p. 413; Vol. 87, p. 394; Vol. 91, p. 378; Vol. 96, p. 323 ; Vol. 100 , p. 293 ; Vol. 105 , p. 303 ; Vol. 120, p. 298 ; Vol. 128, p. 307, and Vol. 131, p. 332.

7 Geneva Convention for the amelioration of the condition of wounded, sick and shipwrecked members of armed forces at sea of 12 August, 1949: United Nations, Treaty Series, Vol. 75, p. 85 ; Vol. 78 , p. 366 ; Vol. 84, p. 414 ; Vol. 87, p. 394 ; Vol. 91, p. 379; Vol. 96, p. 324 ; Vol. 100, p. 294 ; Vol. 120, p. 299 ; Vol. 128, p. 307, and Vol. 131, p. 333.

8 Geneva Convention relative to the treatment of prisoners of war of 12 August, 1949: United Nations, Treaty Series, Vol. 75, p. 135 ; Vol. 78, p. 367 ; Vol. 84, p. 415 ; Vol. 87, p. 395 ; Vol. 91 , p. 380 ; Vol. 96 , p. 325 ; Vol. 100, p. 294 ; Vol. 120, p. 299 ; Vol. 128, p. 308, and Vol. 131, p. 333.

- Geneva Convention relative to the protection of civilian persons in time of war of 12 August 1949 : United Nations, Treaty Series, Vol. 75, p. 287; Vol. 78, p. 368 ; Vol. 84, p. 416 ; Vol. 87 , p. 395 ; Vol. 91 , p. 381 ; Vol. 96 , p. 326 ; Vol. 100, p. 295 ; Vol. 120 , p. 300 ; Vol. 128, p. 308 , and Vol. 131, p. 333.

No. 1832 
to participation in $(a)$ the Convention ${ }^{1}$ on International Civil Aviation opened for signature at Chicago on December 7, 1944, and, as soon as Japan is itself a party to that Convention, to accept the International Air Services Transit Agreement ${ }^{2}$ also opened for signature at Chicago on December 7,1944 ; and $(b)$ the Convention $^{3}$ of the World Meteorological Organization opened for signature at Washington on October 11, 1947.

1 United Nations, Treaty Series, Vol. 15, p. 295 ; Vol. 26, p. 420 ; Vol. 32, p. 402 ; Vol. 33, p. 352 ; Vol. 44 , p. 346 , and Vol. 51, p. 336 .

2 United Nations, Treaty Series, Vol. 84, p. 389.

3 United Nations, Treaty Series, Vol. 77, p. 143, and Vol. 88, p. 454.

No. 1832 


$$
\begin{aligned}
& \text { 希德里望他古 } \\
& \text { 国川急君四四 }
\end{aligned}
$$

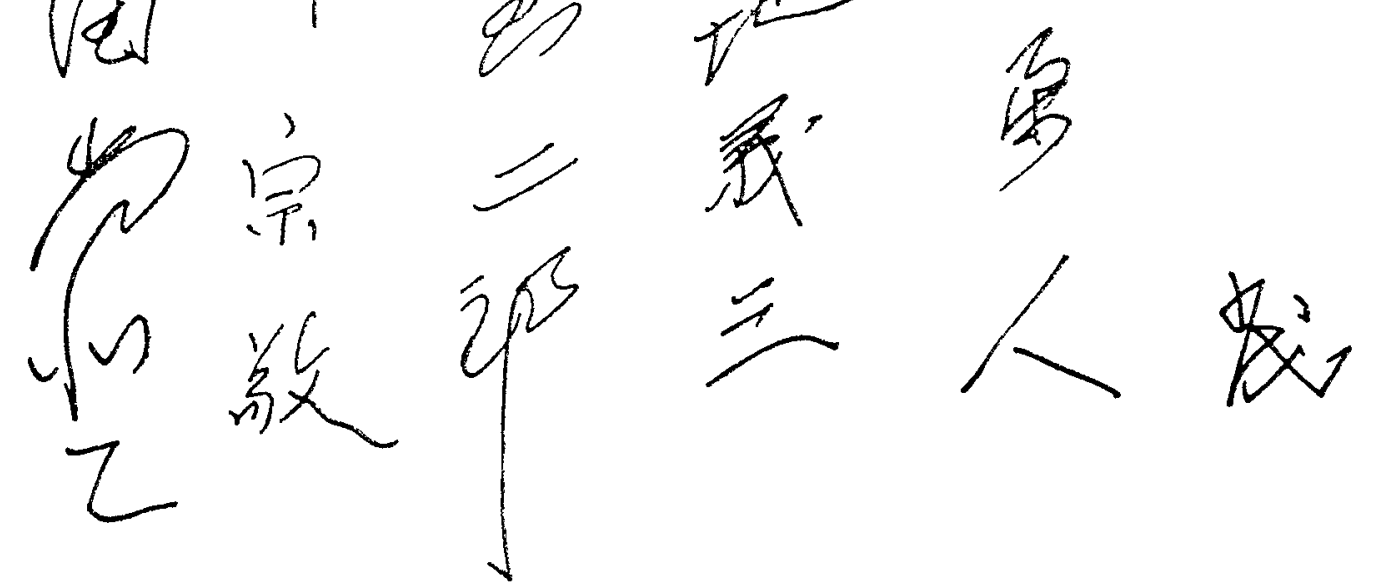


With respect to the Treaty of Peace ${ }^{1}$ signed this day, the Government of Japan makes the following Declaration :

Japan will recognize any Commission, Delegation or other Organization authorized by any of the Allied Powers to identify, list, maintain or regulate its war graves, cemeteries and memorials in Japanese territory; will facilitate the work of such Organizations; and will, in respect of the abovementioned war graves, cemeteries and memorials, enter into negotiations for the conclusion of such agreements as may prove necessary with the Allied Power concerned, or with any Commission, Delegation or other Organization authorized by it.

Japan trusts that the Allied Powers will enter into discussions with the Japanese Government with a view to arrangements being made for the maintenance of any Japanese war graves or cemeteries which may exist in the territories of the Allied Powers and which it is desired to preserve.

I See p. 45 of this volume.

No. 1832 
DONE at the city of San Francisco this eighth day of September 1951.

FaIt en la ville de San-Francisco, ce huitième jour du mois de septembre 1951.

Hecho en la ciudad de San Francisco, el ocho de Septiembre de 1951.
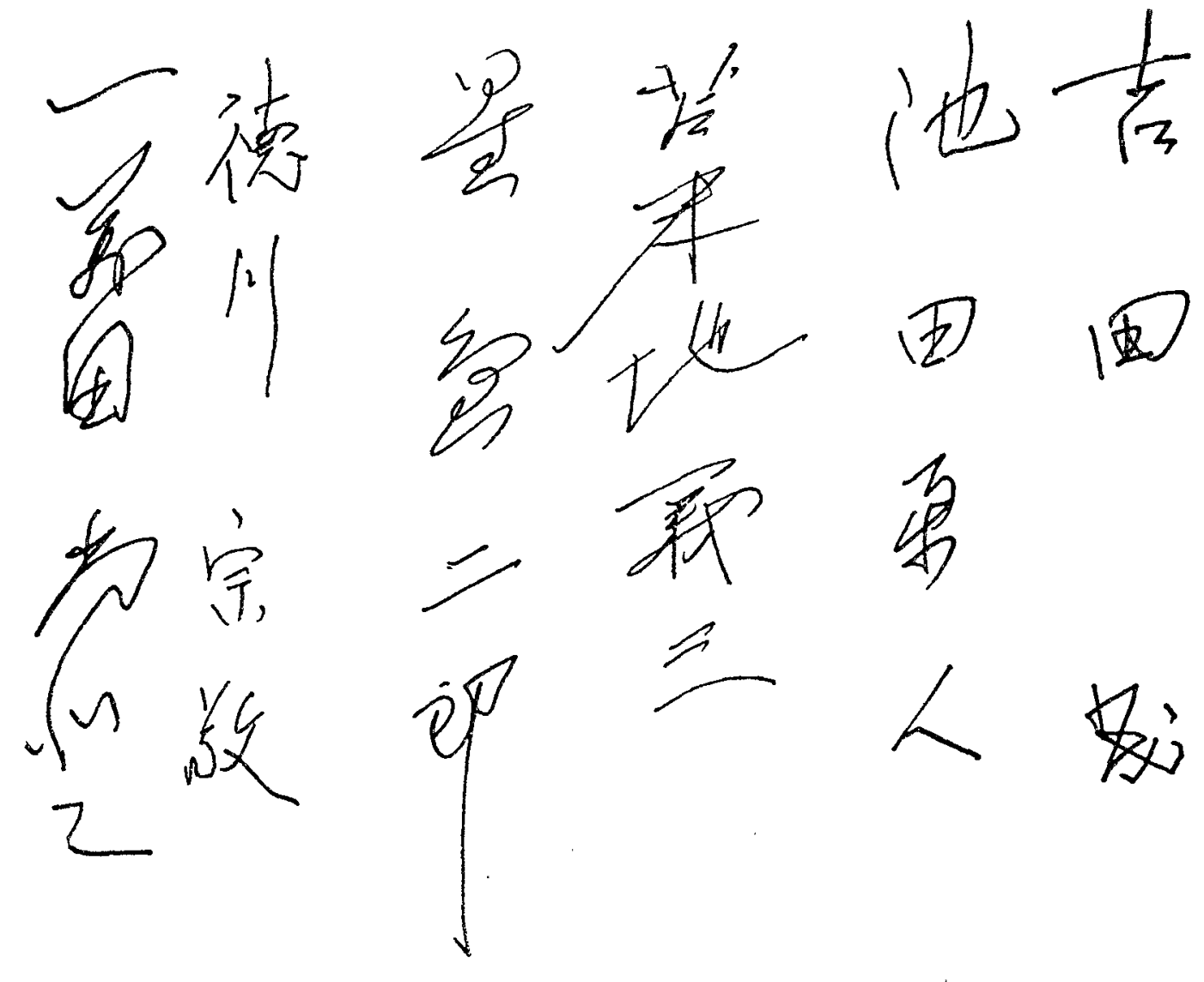